\title{
PROCESSING OF A NIGERIAN COLUMBITE- RICH ILMENITE ORE FOR IMPROVED INDUSTRIAL APPLICATION BY SULPHURIC ACID SOLUTION
}

\section{PENGOLAHAN BIJIH KOLUMBIT-KAYA ILMENIT DARI NIGERIA UNTUK APLIKASI INDUSTRI MENGGUNAKAN LARUTAN ASAM SULFAT}

\author{
ALAFARA A. BABA ${ }^{1}$, SUNDAY O. JACOB ${ }^{1}$, DAUD T. OLAOLUWA ${ }^{2}$, ABDULRAHMAN \\ ABUBAKAR ${ }^{2}$, ADEOLA A. WOMILOJU ${ }^{1}$, FAUSAT T. OLASINDE ${ }^{1,3}$ and AISHAT Y. \\ ABDULKAREEM ${ }^{1,4}$ \\ 1 Department of Industrial Chemistry, University of Ilorin \\ P.M.B. 1515, llorin-240003, Nigeria. \\ Ph. +234803501030 \\ E-mail: alafara@unilorin.edu.ng \\ ${ }^{2}$ Department of Chemistry, University of llorin \\ P.M.B. 1515, llorin-240003, Nigeria. \\ ${ }^{3}$ Chemistry Advanced Research Centre, Sheda Science and Technology Complex, FCT \\ P.M.B. 186, Garki, Abuja, Nigeria. \\ ${ }^{4}$ National Mathematical Centre, Sheda, Kwali \\ P.M.B. 118, Abuja, Nigeria.
}

\begin{abstract}
Due to increasing technological advancements, the demand for pure niobium products emanated from columbite ore processing has led to the wide array of its application in capacitors, nuclear uses, superconducting RF cavities, an electromagnetic radiation detector, medical devices, and aerospace among others. Therefore, this paper focuses on the kinetics of dissolution of a Nigerian Columbite mineral in sulphuric acid solution for improved industrial applications. The effects of acid concentration, reaction temperature and particle size on the ore dissolution rate were examined. Experimental results showed that the ore dissolution increases with increasing acid concentration and temperature and decreases with increasing particle size fraction. With $2 \mathrm{~mol} / \mathrm{L} \mathrm{H}_{2} \mathrm{SO}_{4}$ solution, $60.2 \%$ of the ore dissolved within 120 minutes using $<90 \mu \mathrm{m}$ particle size at a temperature of $75^{\circ} \mathrm{C}$ with moderate stirring (300 rpm). The unleached products were analyzed and found to contain siliceous compounds applicable as industrial by-products. The calculated activation energy (Ea) deduced to be $30.3 \mathrm{~kJ} / \mathrm{mol}$ supported the proposed diffusion reaction mechanism for the first order dissolution process with a collision factor of 0.12 per minute. Hence, the dissolution data obtained in this study is an indication of thermodynamic feasibility for Nigeria Columbite ore fitness in improving science and technology for economic growth and development.
\end{abstract}

Keywords: columbite-rich ilmenite ore, leaching, sulphuric acid, dissolution kinetics, product characterization

\begin{abstract}
ABSTRAK
Dengan meningkatnya kemajuan teknologi, permintaan untuk produk niobium murni yang berasal dari pengolahan bijih kolumbit telah menghasilkan beragamnya aplikasi seperti: kapasitor, penggunaan nuklir, rongga RF superkonduktor, detektor radiasi elektromagnetik, peralatan medis, dan kedirgantaraan dan lain lain. Oleh karena itu, makalah ini difokuskan untuk mempelajari kinetika mineral columbit dari Nigeria menggunakan larutan asam sulfat untuk aplikasi industri yang lebih baik. Efek dari konsentrasi asam, suhu reaksi dan ukuran partikel pada tingkat pelarutan bijih dipelajari.
\end{abstract}


Hasil percobaan menunjukkan bahwa pelarutan bijih meningkat dengan menigkatnya konsentrasi asam dan suhu dan menurun dengan meningkatnya fraksi ukuran partikel. Dengan larutan $\mathrm{H}_{2} \mathrm{SO}_{4} 2$ mol/L, dan dipanaskan pada suhu $75^{\circ} \mathrm{C}$ selama 120 menit dengan kecepatan pengadukan $300 \mathrm{rpm}$ pada ukuran partikel <90 m, maka didapat bijih terlarut sebanyak $60,2 \%$. Produk yang tidak terlarut dianalisis dan ditemukan mengandung senyawa silika yang dapat dimanfaatkan sebagai produk samping. Energi aktivasi terhitung (Ea) sebesar 30,3 kJ / mol, mendukung mekanisme reaksi difusi yang terjadi untuk proses pelarutan orde pertama dengan faktor tumbukan 0,12 per menit. Hal ini menunjukkan bahwa data pelarutan yang diperoleh dari penelitian ini merupakan indikasi kelayakan termodinamika kemampuan bijih kolumbit Ngeria dalam meningkatkan ilmu pengetahuan dan teknologi untuk pertumbuhan ekonomi dan pembangunan.

Kata kunci: bijih kolumbit-kaya ilmenit, pelindian, asam sulfat, kinetika pelarutan, karakterisasi produk

\section{INTRODUCTION}

Columbite, $(\mathrm{Fe}, \mathrm{Mn})(\mathrm{Nb}, \mathrm{Ta})_{2} \mathrm{O}_{6}$ is a niobiumtantalum (Nb-Ta) containing mineral with niobium occurring significantly than tantalum (Ayanda and Adekola, 2011; Ayanda, Adekola and Fatoki, 2012). This black mineral group contains $5-30 \%$ tantalum and $55-78 \% \mathrm{Nb}_{2} \mathrm{O}_{5}$ by mass (Agulyansky, 2004). However, the commercial value of $\mathrm{Nb}$ and $\mathrm{Ta}$ in the metallurgical, nuclear and electronic industries, etc. makes their recovery desirable in relatively concentrated forms. For example, the Tantalum-Niobium International Study Centre (TNISC) have reported that $\mathrm{Ta}$ from raw materials exceeded 5 million tones $\mathrm{Ta}_{2} \mathrm{O}_{5}$ during 1999, while the total supply of $\mathrm{Nb}$ from raw materials ran at $150-160$ million tones $\mathrm{Nb}_{2} \mathrm{O}_{5}$. Consequently, the increasing demand has firmed the prices of the raw materials for this mineral and thus encouraged new production from the small manufacturers in Africa, Brazil, and China till date (Liriden, 1999; Zhou, Zheng and Zhang, 2005). Therefore, the development of $\mathrm{Ta}$ and $\mathrm{Nb}$ industry till date has been driven by the development of science and technology and the continuously increasing use of electronic products that consume these elements (He, Zhang and Liu, 2006; Lv et al., 2012). The chemical separation or purification of $\mathrm{Ta}$ and $\mathrm{Nb}$ from their ore is a complex and difficult task due to the chemical and physical similarities of the two elements such as their ionic radii, resistance to chemical attack and the ease with which their compounds are hydrolyzed in aqueous solution (Morrison and Freiser, 1962).

It has however been reported that the commercially successful routes in the separation of the aforementioned materials are tailored to the Marignac process and the alternative route by U.S Bureau of Mines Ames Laboratory of lowa State University in the 1950's. The processing of metals in both routes summarized in equation (1) involves the complexation of the two metal ions with smaller fluoride anions $\left(F^{-}\right)$during the mineral dissolution (Nete, Purcell and Nel, 2014):

$\left(\mathrm{Ta} / \mathrm{Nb}{ }_{2}\right) \mathrm{O}_{5}+$ fluoride source $(\mathrm{HF}$, $\left.\mathrm{HF} / \mathrm{H}_{2} \mathrm{SO}_{4} / \mathrm{NH}_{4} \mathrm{~F} . \mathrm{HF}\right) \rightarrow \mathrm{TaF}_{7}{ }^{2-} / \mathrm{NbOF}_{5}{ }^{2-}(1)$

Also, chlorination of the raw materials followed by distillation of resultant $\mathrm{Nb}$ and $\mathrm{Ta}$ chloride complexes is another successful separation route to producing high purity $\mathrm{Nb}$ of industrial value according to the following stoichiometry (equation 2):

$(\mathrm{Ta}, \mathrm{Nb})_{2} \mathrm{O}_{6}+$ Chloride $\left(\mathrm{Cl}_{2}, \mathrm{NaCl},+\mathrm{FeCl}_{3}\right)$ $\rightarrow(\mathrm{Ta}, \mathrm{Nb}) \mathrm{Cl}_{5}$

However, the environmental consideration and material design are still drawbacks of the two aforementioned routes. For the economic feasibility, eco-friendly considerations, efficient extraction, flexibility for production of variety of by-products and suitability for treatment of low and complex grade ores, hydrometallurgical process involving leaching and solvent extraction as unit operation is a versatile preferred route for the production of columbite products from its raw material to obtain valuable products of industrial standards. Hence, the present study is aimed at establishing the optimal leaching and kinetic conditions for treating a Nigerian columbite-rich ilmenite ore with the sulphuric acid solution. The effects of some important leaching parameters such as leachant concentration, reaction temperature, and particle size on the extent of the ore dissolution were appraised for better prediction of the dissolution kinetics of the extraction process. 


\section{MATERIALS AND METHODS}

\section{a. Sample Characterization}

The sample under investigation was obtained from Kuru town, Jos South Local Government Area of Plateau State, Nigeria. The ore sample was grounded with an acetone-rinsed mortar and pestle to reduce to fine particle fractions. The pulverized ore sample was then sieved into three different size fractions of $<90 \mu \mathrm{m}, 90 \mu \mathrm{m}$ and $112 \mu \mathrm{m}$ using ASTM standard sieves. The size fraction of $<90 \mu \mathrm{m}$ was used for the leaching studies and ore characterization due to its large surface area unless otherwise stated.

The chemical composition was ascertained using the EDXRF spectrophotometer (EDX3600B). The machine was calibrated using silver standard, and the analysis was carried out using ore standard calibration curve. The mineralogical purity was carried out using GBC Enhanced Mini Material Analyzer (EMMA) X-ray diffractometer, with the following scanning parameters; tube anode: $\mathrm{Cu}$, Wavelength: 1.54056, Scan speed: 2.00, Step size: 0.05. The ore morphological structure was carried out using a Leo1450 withaLaB6 filament. Here, the samples were viewed at $10 \mathrm{kV}, 13 \mathrm{~mm}$ working distance and were carbon coated. The loss of mass on ignition (LOMOI) and moisture content (MC) of the pulverized columbite ore were carried out as previously reported by Baba, Adekola and Faseki, 2006.

\section{b. Leaching Procedure}

The dissolution of Columbite ore was examined by sulphuric acid solutions and the effects of acid concentration, reaction temperature and particle size on the extent of ore dissolution were investigated. The leaching experiment was performed using a $250 \mathrm{ml}$ Pyrex glass reactor equipped with a magnetic stirrer; heat and stirring speed were supplied and monitored by a control unit. For each leaching test, $10 \mathrm{~g} / \mathrm{L}$ ore and the leaching solution of defined concentrations were introduced into the reactor at a set of experimental conditions. The content was then heated under moderate stirring, at a reaction temperature of $55^{\circ} \mathrm{C}$ at various reaction times of 5 to 120 minutes. At the end of each leaching test, the system was cooled and the slurry in the reactor was filtered, the resultant solid was washed, dried at $80^{\circ} \mathrm{C}$ for 60 minutes and weighed (Baba and Adekola, 2010; Baba et al., 2017). The fraction of ore reacted ( $\alpha$ ) at various times was calculated according to the expression:

$(\alpha)=\frac{M_{1}-M_{2}}{M_{1}}$

Where $\alpha=$ fraction of columbite ore reacted at time $t$ ( $\mathrm{min})$

$M_{1}=$ Mass of columbite ore sample introduced into the reactor before leaching(s)

$M_{2}=$ Mass of unreacted columbite ore after leaching(s).

Also, the unleached product at optimal leaching conditions was analyzed by XRD and SEM equipped with EDS technique [11] aimed at better understanding of the dissolution mechanism. Physico-chemical examination of the raw ore was also carried out as detailed elsewhere (Baba et al., 2003; Baba, Adekola and Faseki, 2006).

\section{RESULTS AND DISCUSSION}

\section{Characterization}

The elemental analysis of $<90 \mu \mathrm{m}$ pulverized columbite ore is shown in Figure 1.

The energy dispersive $\mathrm{X}$-ray fluorescence of the pulverized columbite ore in Figure 1 shows that the major element in the ore and their varying percentages are $\mathrm{Nb}(4.4 \%), \mathrm{Ti}$ $(40.6 \%)$, Fe (31.3\%), Sn (16.7\%), Mn $(1.5 \%)$, and $S(2.3 \%)$. Other elements such as $\mathrm{Si}, \mathrm{Al}, \mathrm{Cu}, \mathrm{Au}$, and $\mathrm{Mo}$ are in trace amounts $(\leq 1 \%)$. The $\mathrm{X}$-ray diffraction spectral of the raw ore showed that it contains primarily the following: (1) $\mathrm{Fe}\left(\mathrm{TiO}_{3}\right)$ (Ilmenite)\{01-075-0519\}, (2) ( $\mathrm{Mn}, \mathrm{Fe}) \mathrm{Nb}_{2} \mathrm{O}_{6}$ (Columbite)\{01-016-0337\} as summarized in Figure 2.

The structural morphology of the pulverized columbite ore sample was examined by the Scanning Electron Microscope (SEM) at two magnifications of $10 \mu \mathrm{m}$ and $20 \mu \mathrm{m}$ as shown in Figure 3. 
INDONESIAN MINING JOURNAL Vol. 21, No. 1, April 2018 : 9 - 19

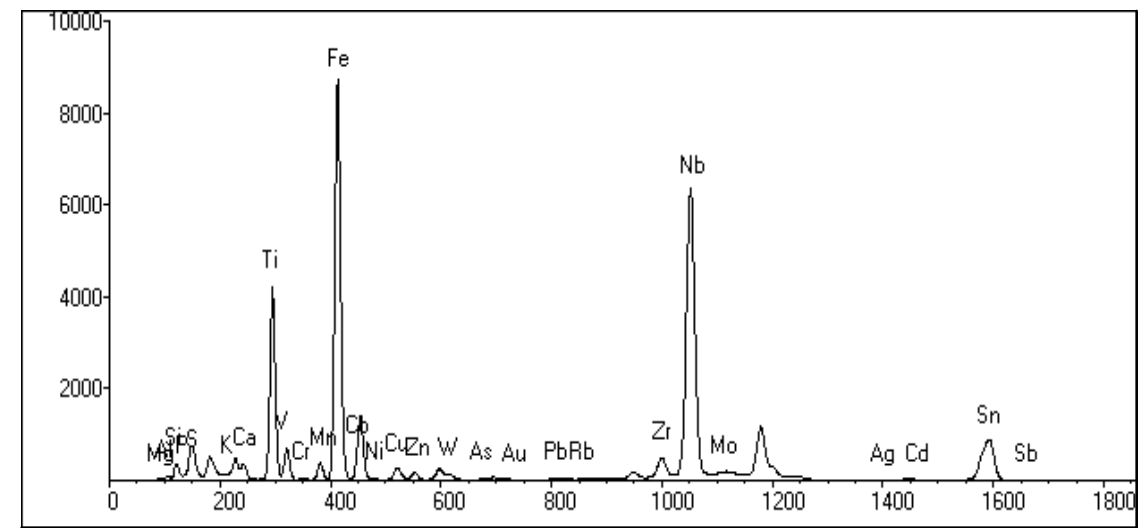

Figure 1. EDXRF of $<90 \mu \mathrm{m}$ pulverized columbite ore.

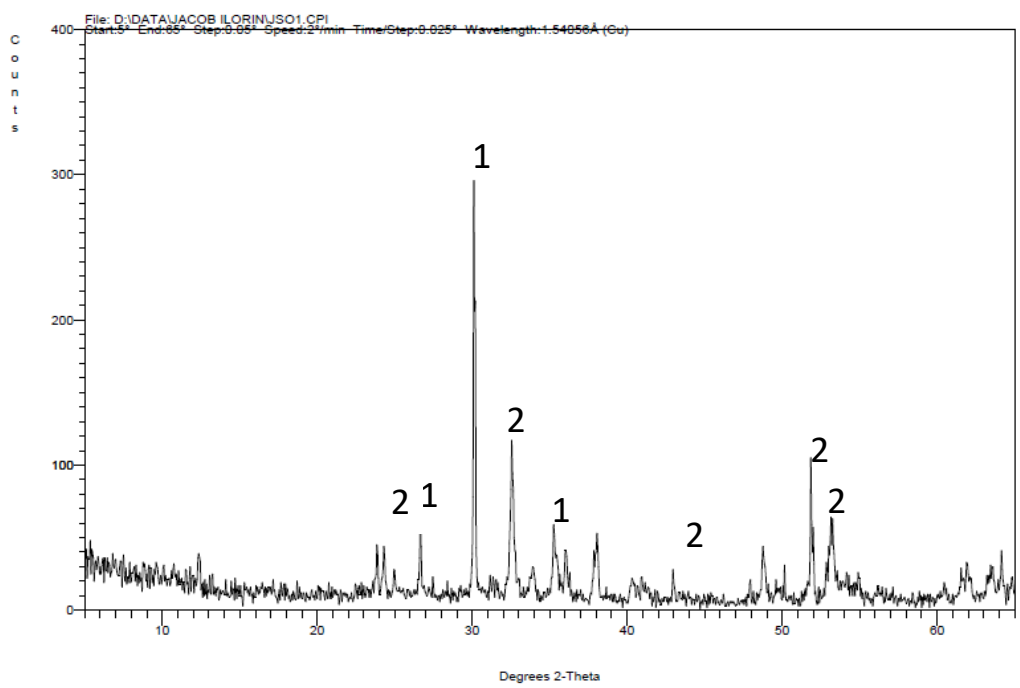

Figure 2. X-ray diffraction pattern of pulverized columbite ore, showing the primary compounds identified with their respective Joint Committee on Powder Diffraction Standard (JCPDS) file number used for peak assignment. 1: $\mathrm{Fe}\left(\mathrm{TiO}_{3}\right)$ (Ilmenite)\{01-075-0519\}, 2: (Mn,Fe)Nb2O6 (Columbite)\{01-016-0337\}.

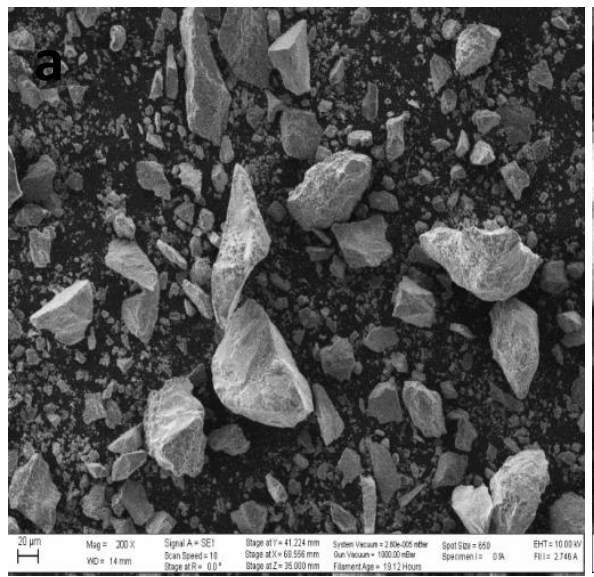

(a)

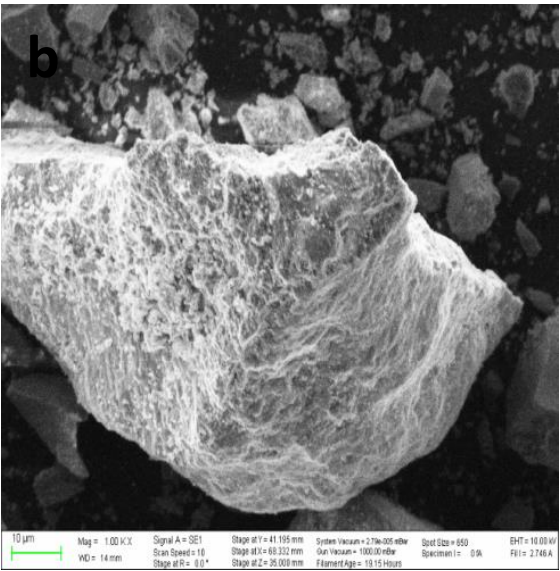

(b)

Figure 3. SEM images of pulverized columbite ore at different magnifications (a: x200; b: x100). 
The SEM image (Figures $3 a$ and b) shows the prismatic shape and macrometric size of the raw columbite. The assay of the pulverized columbite ore through EDS analysis (Figure 4) gave $\mathrm{O}(41.67 \%)$, $\mathrm{Ti}$ $(18.10 \%)$, Fe (17.35), $\mathrm{Nb}(2.32 \%)$ and $\mathrm{C}$ (20.56\%).

The calculated moisture content and the loss of mass on ignition of the raw ore are $0.8 \%$ and $0.5 \%$, respectively. These values can be used to make appropriate analytical corrections with respect to the state of dryness and other impurities in the ore. The $\mathrm{pH}$ of the pulverized ore was also tested to be 7.2 , affirming that the surface of the ore is slightly basic.

\section{Dissolution Studies}

\section{Effect of sulphuric acid concentration}

The effect of sulphuric acid $\left(\mathrm{H}_{2} \mathrm{SO}_{4}\right)$ concentration ranging between 0.1 - 4.0 $\mathrm{mol} / \mathrm{L}$ on the columbite ore dissolution at 55 ${ }^{\circ} \mathrm{C}$ at various leaching times with moderate stirring (300 rpm) was studied. The fraction of the ore reacted at various leaching times is plotted for the different $\mathrm{H}_{2} \mathrm{SO}_{4}$ concentrations as shown in figure 5.

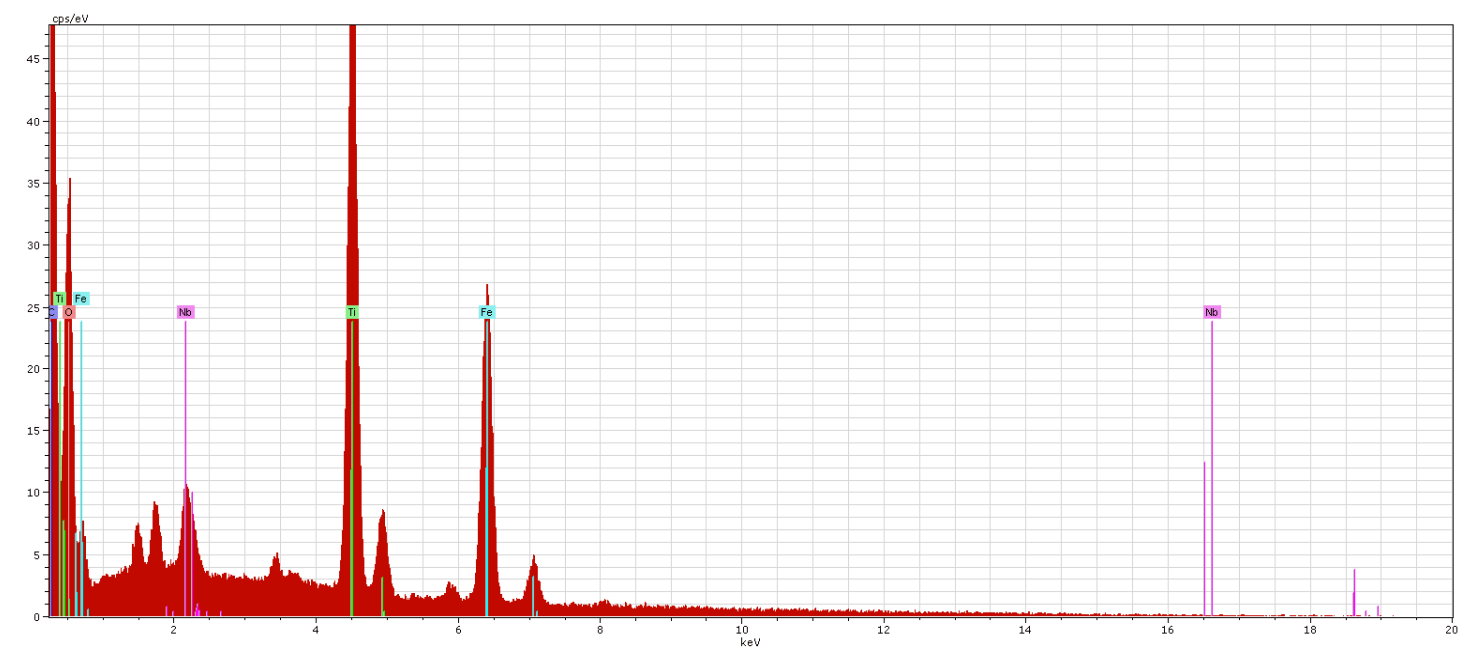

Figure 4. EDS result of raw columbite ore

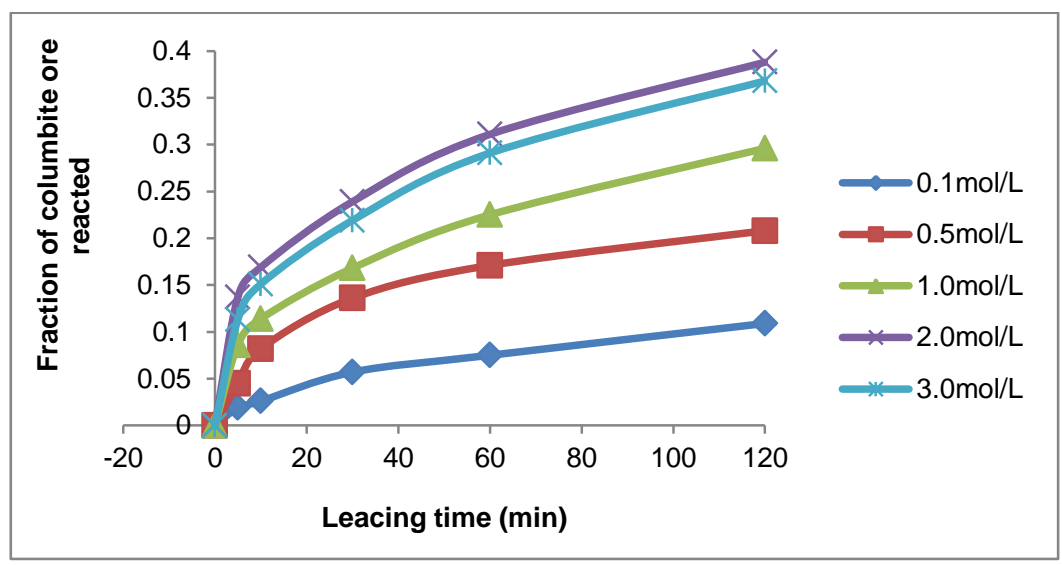

Figure 5. Effect of $\mathrm{H}_{2} \mathrm{SO}_{4}$ concentrations on columbite ore dissolution at various leaching time (min.). Experimental conditions: $\mathrm{H}_{2} \mathrm{SO}_{4}$ concentration $=0.1-4.0 \mathrm{~mol} / \mathrm{L}$; Temperature $=55^{\circ} \mathrm{C}$, Particle size $=$ $<90 \mu \mathrm{m}$; Solid-liquid ratio $=10 \mathrm{~g} / \mathrm{L}$ with moderate stirring at $300 \mathrm{rpm}$. 
As summarized in Figure 5, the dissolution of columbite ore increases with increasing acid concentration and this implies that the concentration of $\mathrm{H}_{2} \mathrm{SO}_{4}$ has a significant effect on columbite ore dissolution. At a temperature of $55{ }^{\circ} \mathrm{C}$, about $38.8 \%$ and $36.8 \%$ of the ore reacted by $2 \mathrm{~mol} / \mathrm{L}$ and 3.0 $\mathrm{mol} / \mathrm{L} \mathrm{H}_{2} \mathrm{SO}_{4}$ solution within 120 minutes. As the extent of ore dissolution decreases with increasing leachant concentration, $2.0 \mathrm{~mol} / \mathrm{L}$ $\mathrm{H}_{2} \mathrm{SO}_{4}$ solution known to have higher dissolution data was recorded as the optimum concentration and kept for further studies to optimize other parameters such as reaction temperature and particle size variations. The dissolution of columbite by sulphuric acid solution can be represented by the following stoichiometries:

$\mathrm{FeNb}_{2} \mathrm{O}_{6}+2 \mathrm{H}_{2} \mathrm{SO}_{4} \rightarrow \mathrm{Nb}_{2} \mathrm{O}_{5} \cdot \mathrm{SO}_{3}+\mathrm{FeSO}_{4}$

$+2 \mathrm{H}_{2} \mathrm{O}$

$\mathrm{MnNb}_{2} \mathrm{O} 6+2 \mathrm{H}_{2} \mathrm{SO}_{4} \rightarrow \mathrm{Nb}_{2} \mathrm{O}_{5} \cdot \mathrm{SO}_{3}+\mathrm{MnSO}_{4}$ $+2 \mathrm{H}_{2} \mathrm{O}$

Under these conditions, all the elements present with the columbite ore apparently dissolved to produce a leach solution containing niobium oxides.

\section{Effect of reaction temperature}

The effect of reaction temperature on the dissolution of columbite ore was studied over temperature ranges of $25-75^{\circ} \mathrm{C}$ (Figure $6)$.

From figure 6, it is evident that the dissolution of columbite ore increases with increasing temperatures at different contact times. For instance, at $25^{\circ} \mathrm{C}$, after 5 minutes, the dissolution of columbite increases from 5.4\% to $25.6 \%$ during 120 minutes and reaction reaches $19 \%$ and $60.2 \%$ during 5 and 120 minutes of reaction at $75^{\circ} \mathrm{C}$, respectively. Hence, these observations can be attributed to the fact that particles react faster with increasing reaction temperature. However, reaction temperature beyond $75^{\circ} \mathrm{C}$ was not considered in this study because of the excessive loss of acid through evaporation.

\section{Effect of particle size fractions}

The effect of particle diameter on the dissolution rate of columbite ore was examined with three different particle size fractions: $<90 \mu \mathrm{m}, 90 \mu \mathrm{m}$ and $112 \mu \mathrm{m}$ by 2 $\mathrm{mol} / \mathrm{L} \mathrm{H}_{2} \mathrm{SO}_{4}$ solution at $75^{\circ} \mathrm{C}$. The result of this examination is summarized in figure 7 .

The leaching curves from figure 7 indicate that the rate of columbite dissolution process increases with decreasing particle fraction. This among others things are attributed to the fact that the surface area for reaction becomes more available with decreasing particle size, resulting in an increase in the efficiency of the leaching process. When the specific diameter continues to reduce, more active sites on the solid surface are exposed to the solution, thus, enabling an effective dissolution which enhances metal solubilization. At optimal conditions, dissolution reached $21.03 \%, 39.45 \%$ and $60.12 \%$ using $112 \mu \mathrm{m}, 90 \mu \mathrm{m}$ and $<90 \mu \mathrm{m}$, respectively.

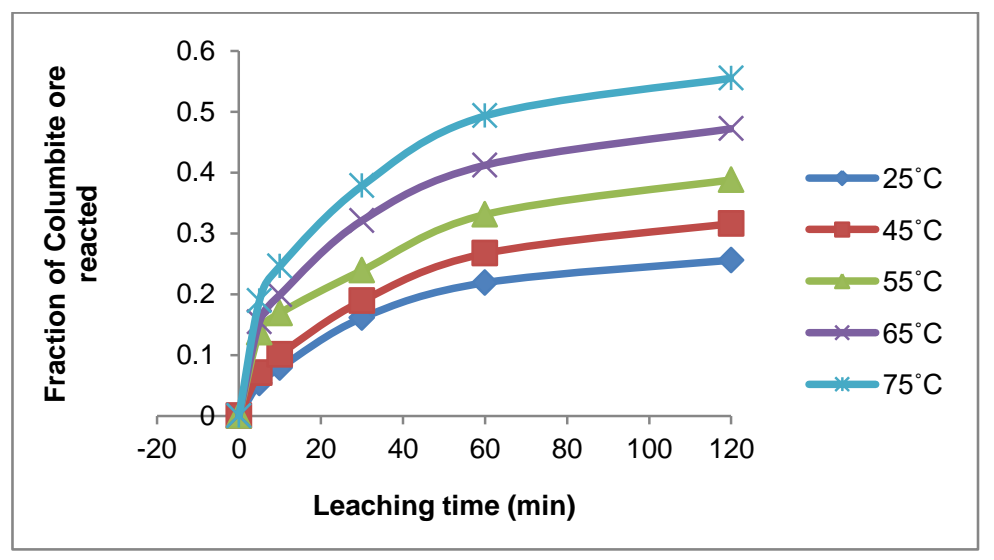

Figure 6. Effect of temperature on columbite ore dissolution at various leaching time.

Experimental conditions: $\left[\mathrm{H}_{2} \mathrm{SO}_{4}\right]=2 \mathrm{~mol} / \mathrm{L}$, Temperature $=25-75^{\circ} \mathrm{C}$ and Particle size $=<90 \mu \mathrm{m}$, Solidliquid ratio $=10 \mathrm{~g} / \mathrm{L}$ with moderate stirring at $300 \mathrm{rpm}$. 


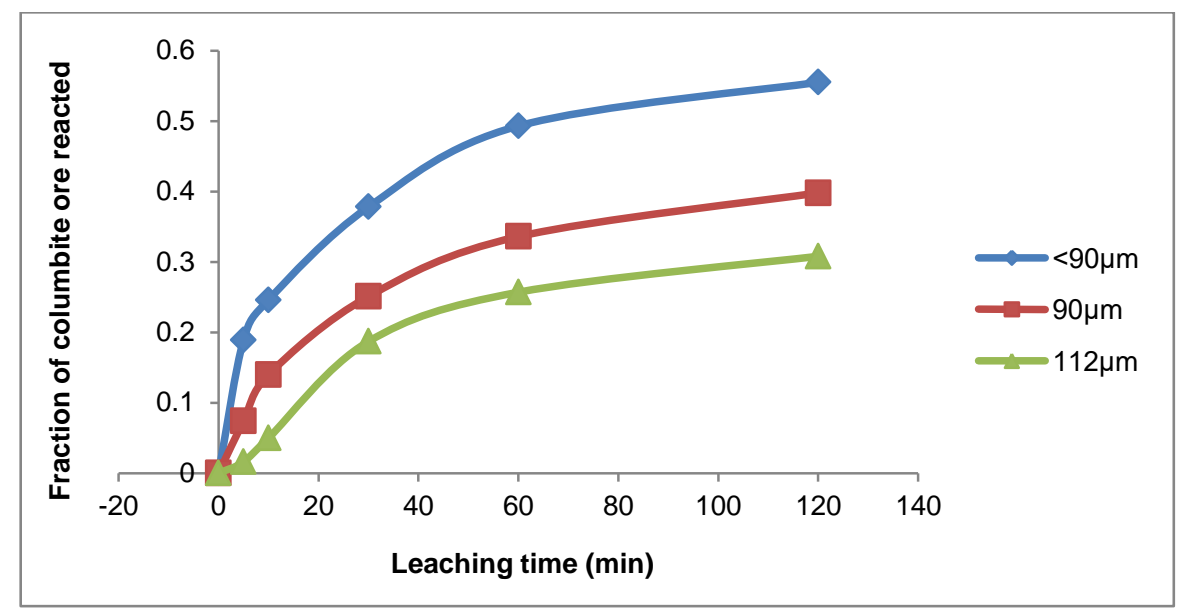

Figure 7. Effect of particle size on columbite ore dissolution.

Experimental conditions: Temperature $=75^{\circ} \mathrm{C}, \mathrm{H}_{2} \mathrm{SO}_{4}$ Concentration $=2 \mathrm{~mol} / \mathrm{L}$, Solid-liquid ratio $=10$ $\mathrm{g} / \mathrm{L}$ with moderate stirring at $300 \mathrm{rpm}$.

\section{Dissolution Kinetics Analysis}

In hydrometallurgy, the shrinking core models are widely applied to describe the shrinkage of ore particles during the leaching of minerals. The central unit operations in the hydrometallurgical ore treatment is the shrinking core models and are mostly widely applied for a better understanding of the ore dissolution (Espiari, Rashchi and Sadrnezhaad, 2006; Szubert, Łupiński and Sadowski, 2006). The shrinking core model assumes a non-porous particle with starting radius $r_{0}$ dissolving over the duration of time in a liquid reagent of concentration $\mathrm{C}_{0}$. The reaction takes place at the surface of the particle and will shrink with time. The shrinking core model takes into account two different limiting conditions namely chemical reaction rate and the ash diffusion rate. The simplified equation of the chemical reaction and diffusion control shrinking core model is expressed respectively as follows (Levenspiel, 1972; Jin, Warren and Henein, 1984; Aydogan, Aras and Canbazoglu, 2005; Santos et al., 2010; Baba et al., 2017):

$1-(1-\alpha)^{\frac{1}{3}}=k_{\mathrm{r}} \mathrm{t} \ldots \ldots \ldots . .$.
$1-\frac{2}{3} \alpha-(1-\alpha)^{\frac{2}{3}}=k_{\mathrm{d}} \mathrm{t}$.

where $\alpha$ is the fraction of columbite ore reacted and $k_{d}, k_{r}$ and $k_{f}$ are the rate constants. The dissolution data obtained in this study were subjected to the aforementioned models and the examinations of the plots of the kinetic equations as a function of leaching time gives a perfectly straight line for the diffusion controlled model only and all other data were treated accordingly to obtain the relations relative to the determination of the order of reaction and apparent activation energy for better understanding of the dissolution mechanisms.

The experimental rate constant $k_{d}$, were determined from the plot of slope in Figure 8 and the plot of $I n k_{d}$ against $\ln \left[\mathrm{H}_{2} \mathrm{SO}_{4}\right]$ was used to determine the order of the reaction as shown in Figure 9.

The reaction rate constant, $k_{d}$ is also defined by the Arrhenius equation as shown by the expression in equations (7) and (8):

$\begin{aligned} k_{d} & =A \exp ^{(-E a / R T)} \\ \operatorname{lnk}_{d} & =\ln A+\left(-\frac{E a}{R}\right) \cdot \frac{1}{T}\end{aligned}$

Where $\mathrm{A}$ is the collision frequency factor, Ea is the apparent activation energy, $T$ is the absolute temperature and $\mathrm{R}$ is the universal gas constant. From a plot of $\operatorname{InK}_{d}$ versus $\frac{1}{\mathrm{~T}}$ a straight line of $\frac{\mathrm{Ea}}{\mathrm{RT}}$ the slope was obtained for different temperatures. 
INDONESIAN MINING JOURNAL Vol. 21, No. 1, April $2018: 9$ - 19

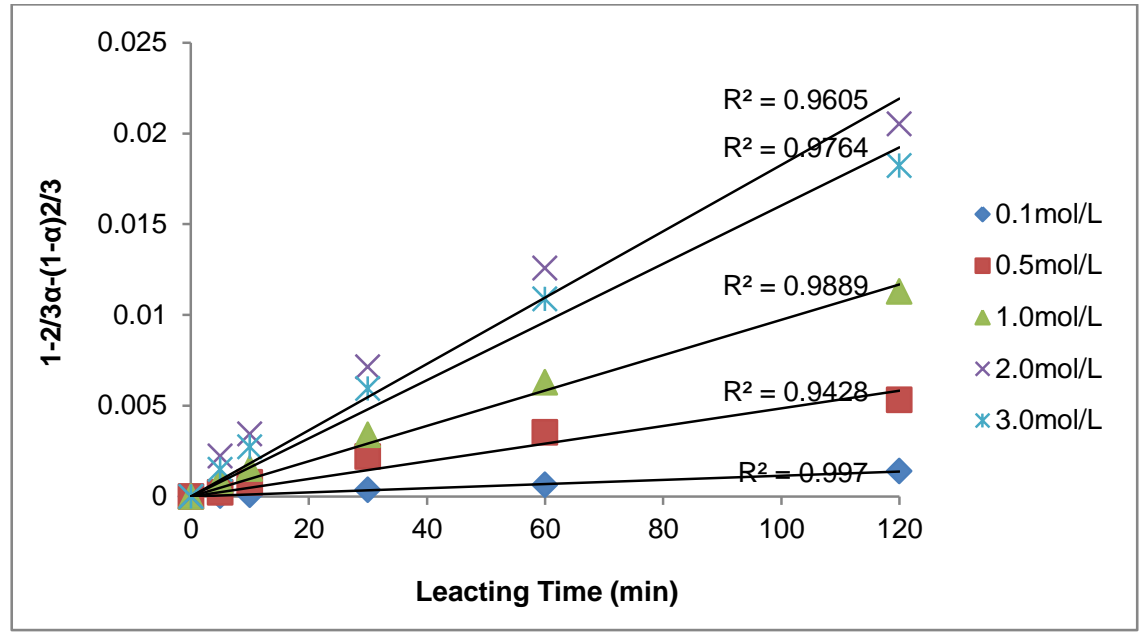

Figure 8. The plot of $1-2 / 3 \alpha-(1-\alpha)^{2 / 3}$ versus leaching time at different $\mathrm{H}_{2} \mathrm{SO}_{4}$ concentrations. Experimental conditions: Same as in figure 5

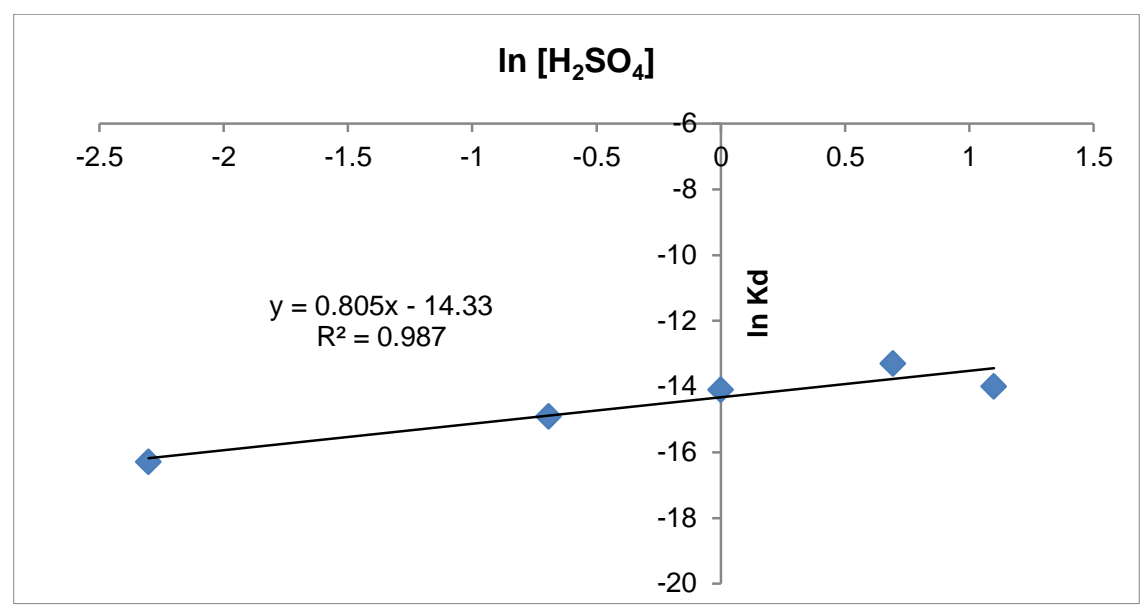

Figure 9. The plot of $\ln \mathrm{K}_{d}$ versus $\ln \left[\mathrm{H}_{2} \mathrm{SO}_{4}\right]$.

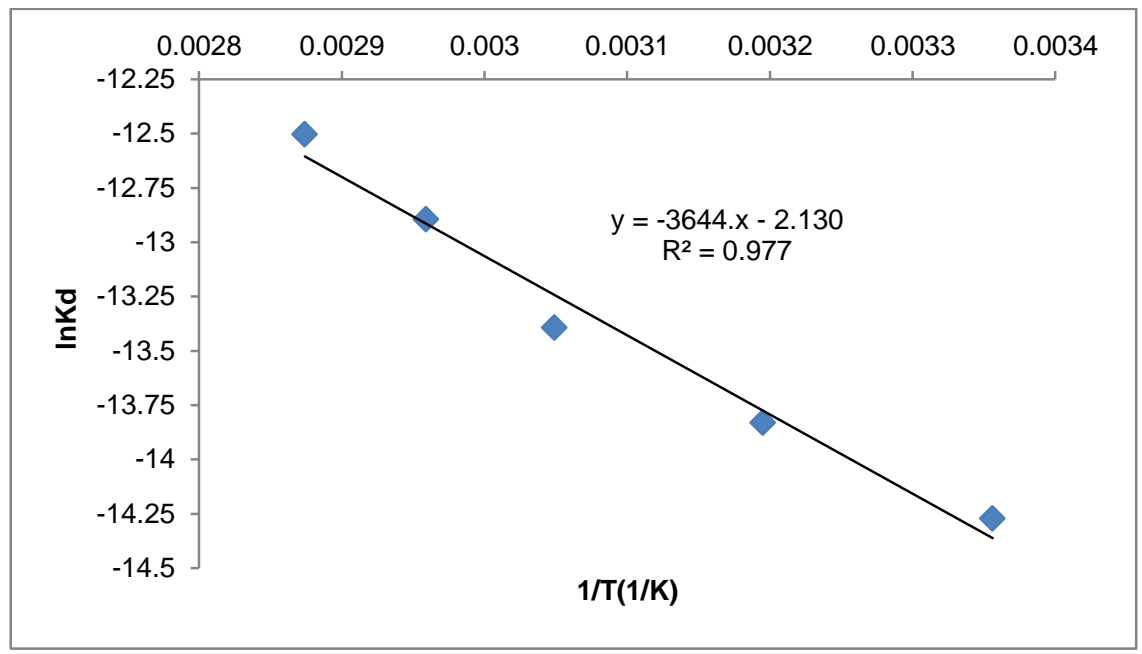

Figure 10. The plot of $\operatorname{lnK}_{d}$ versus $1 / \mathrm{T}$ 
From the Arrhenius plot, the following values were calculated:

$E_{a}=30.3 \mathrm{kJmol}^{-1}$ and $A=1.98 \times 10^{-3} \mathrm{~s}^{-1}$

This value of activation energy clearly suggests a diffusion control through the ash layer for the process as this value is consistent with the values obtained in another fluid-solid reaction system (Gerald et al., 2013).

\section{Residual product analysis}

The residual product formed after optimal leaching conditions were analyzed by XRD, SEM and EDS techniques and the results compared to the columbite ore before leaching. From the EDS result in figure 11, there was a significant increase in Niobium enrichment from $2.13 \%$ to $4.10 \%$ after acid treatment. Also, titanium and iron were leached into solution leaving behind about $7.8 \%$ and $8.76 \%$ respectively in the residual product as shown from EDS spectrum in Figure 11.

The XRD spectrum after optimal leaching conditions corroborates the EDS result reported as the unleached products contained an admixture of ashanite and cristobalite as shown in Figure 12.

Also, the SEM images of the residual product after optimal leaching at $75^{\circ} \mathrm{C}, 120$ minutes contact by $2 \mathrm{~mol} / \mathrm{L}$ sulphuric acid solution is as represented in figure 13 .

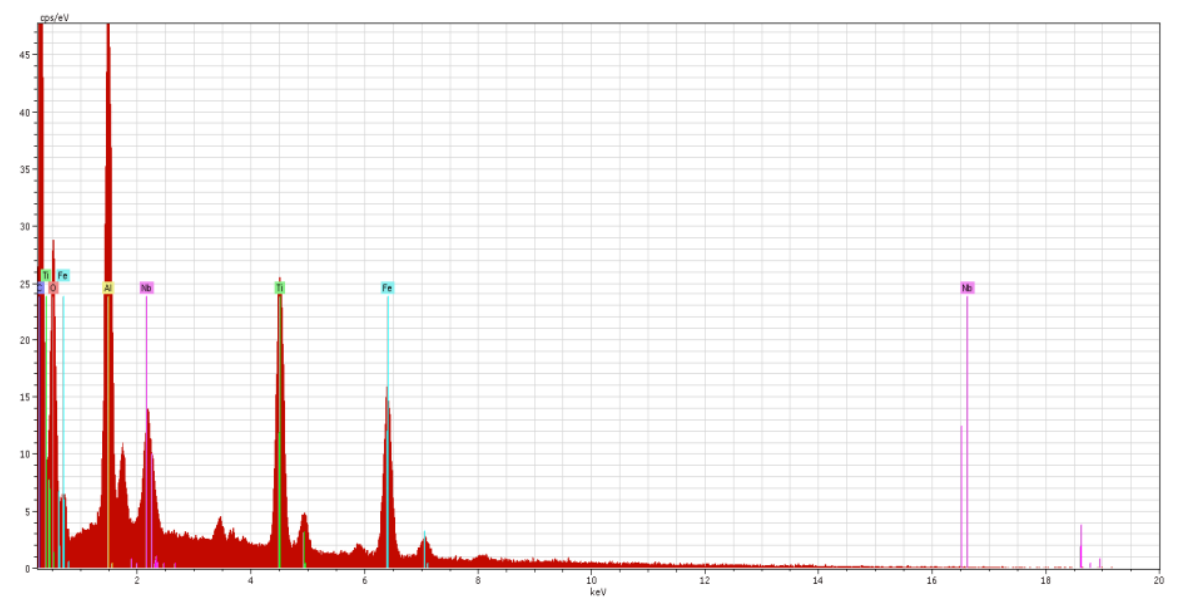

Figure 11. EDS result of leached columbite ore by $\mathrm{H}_{2} \mathrm{SO}_{4}$ solution at optimal conditions.

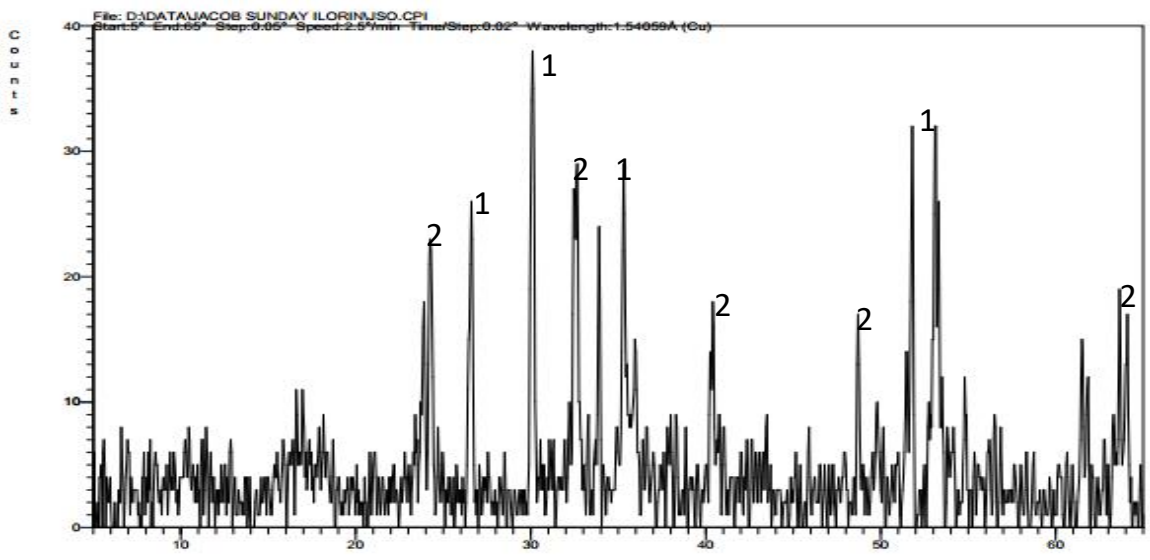

Figure 12. X-ray diffraction pattern of processed columbite ore, showing the major compounds identified:

(1) $(\mathrm{Nb}, \mathrm{W}, \mathrm{Fe}, \mathrm{Mn}) \mathrm{O}_{2}$ (Ashanite) $\{01-022-1114\},(2) \boldsymbol{\alpha}-\mathrm{SiO}_{2}$ (Cristobalite) $\{01-039-1425\}$. 

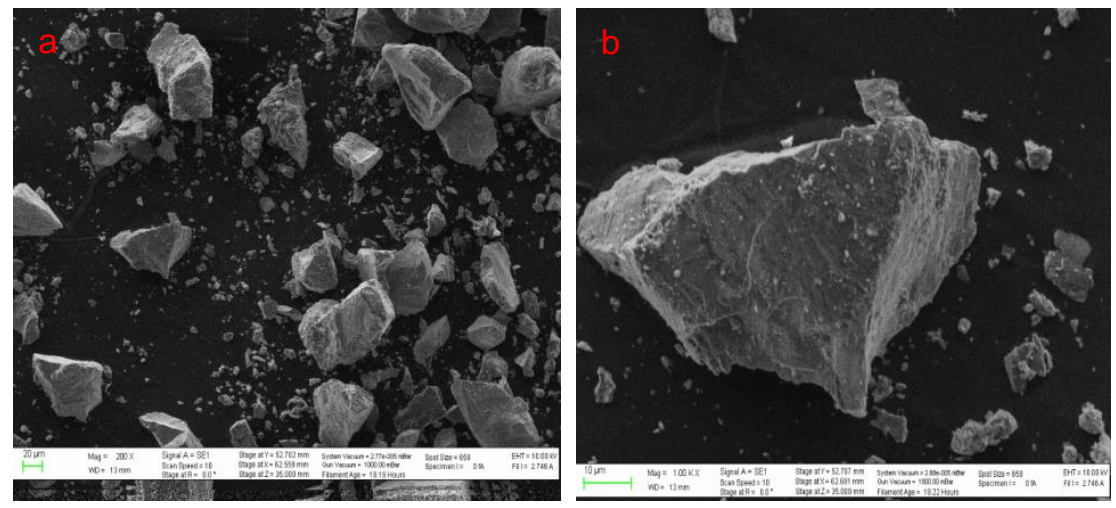

Figure 13. SEM images of leached columbite ore by $\mathrm{H}_{2} \mathrm{SO}_{4}$ solution at optimal conditions at different magnifications (a: $x 200 ; b: x 100)$.

The SEM images of the leached residual product in figure 16 revealed the erosive impact and reduction in grain size as compared to the raw ore (Figure 3), attributed to leaching of the major elements into the solution.

\section{CONCLUSIONS}

This study devoted to the processing of a Nigerian columbite-rich ilmenite ore by sulphuric acid solution was carried out by varying acid concentration, reaction temperature, and particle fraction to assess the extent of the ore dissolution for establishing optimal extraction conditions. The experimental results showed that ore dissolution increases with increasing acid concentration and temperature, but decreases with increasing particle fraction. At optimal leaching $\left(2 \mathrm{~mol} / \mathrm{L} \mathrm{H}_{2} \mathrm{SO}_{4}, 75^{\circ} \mathrm{C}\right.$, $<90 \mu \mathrm{m}$ ), the dissolution reached $60 \%$ within 120 minutes with moderate stirring resulted in niobium ( $\mathrm{Nb}$ ) enrichment from $2.13 \%$ to $4.10 \%$. The dissolution data were fitted to appropriate kinetic models and was found to follow a diffusion controlled mechanism as the calculated activation energy of 30.3 $\mathrm{kJ} / \mathrm{mol}$ supported the proposed reaction mechanism; appear to be a first-order relationship at a defined $\mathrm{H}_{2} \mathrm{SO}_{4}$ concentration. The unleached products examined by X-ray diffraction (XRD) contain siliceous compounds made of admixtures of Ashanite and Cristobalite, could serve as important by-products of industrial values.

\section{ACKNOWLEDGEMENT}

The authors acknowledge Miranda Waldron of the Centre of Imaging and Analysis, University of Cape Town, South Africa for assisting with SEM and EDS analysis.

\section{REFERENCES}

Agulyansky, A. (2004) Chemistry of tantalum and niobium fluoride compounds. Elsevier. Available at: https://www.sciencedirect.com/science/bo ok/9780444516046.

Ayanda, O. S. and Adekola, F. A. (2011) "Comparison of some physicochemical characterization of columbite and tantalite samples from different locations in Nigeria," Chemistry for Sustainable Development, 19, pp. 223-227. Available at:

http://www.sibran.ru/upload/iblock/71e/71 e43979c319107dc6f1037edc9ac6a6.pdf.

Ayanda, O. S., Adekola, F. A. and Fatoki, O. S. (2012) "Dissolution kinetics of columbite in nitric acid," Asian Journal of Chemistry, 24(3), pp. 1087-1090. Available at: http://www.asianjournalofchemistry.co.in/ User/ViewFreeArticle.aspx?ArticleID=24 3_31.

Aydogan, S., Aras, A. and Canbazoglu, M. (2005) "Dissolution kinetics of sphalerite in acidic ferric chloride leaching," Chemical Engineering Journal, 114(1-3), pp. 6772. doi: 10.1016/j.cej.2005.09.005. 
Baba, A. A. and Adekola, F. A. (2010) "Hydrometallurgical processing of a Nigerian sphalerite in hydrochloric acid: Characterization and dissolution kinetics," Hydrometallurgy, 101(1-2), pp. 69-75. doi: 10.1016/j.hydromet.2009.12.001.

Baba, A. A., Adekola, F. A. and Faseki, M. (2006) "A study of the kinetics of the dissolution of a Nigerian tantalite ore in hydrochloric acid," Ife Journal of Science, 7(2). doi: 10.4314/ijs.v7i2.32180.

Baba, A. A., Adekola, F. A., Mesubi, M. A. and Bale, R. B. (2003) "The characterization and lixiviation of sphalerite mineral in some acidic mineral," J. Chem. Soc, Nigeria, 28(1), pp. 40-44. Available at: https://www.researchgate.net/publication /288909925 The characterization and lixiviation_of_sphalerite_mineral_in_som e_acidic_mineral.

Baba, A. A., Olaoluwa, D. T., Alabi, A. G. F., Balogun, A. F., Ibrahim, A. S., Sanni, R. O. and Bale, R. B. (2017) "Dissolution behaviour of a beryl ore for optimal industrial beryllium compound production," Canadian Metallurgical Quarterly, pp. 1-9. doi: 10.1080/00084433.2017.1403107.

Espiari, S., Rashchi, F. and Sadrnezhaad, S. K. (2006) "Hydrometallurgical treatment of tailings with high zinc content," Hydrometallurgy, 82(1-2), pp. 54-62. doi: 10.1016/j.hydromet.2006.01.005.

Gerald, O., Christopher, N., Ayebatonworio, O. and Martin, O. (2013) "Comparative Kinetics of Iron Ore Dissolution in Aqueous HCl-HNO3 System," Journal of Minerals and Materials Characterization and Engineering, 1(4), pp. 153-159. doi: 10.4236/jmmce.2013.14026.

He, J. L., Zhang, H. G. and Liu, W. G. (2006) "Statistics and analysis of the tantalum and niobium industry in China," Race Met. Lett., 25(8), pp. 11-5.

Jin, Z.-M., Warren, G. W. and Henein, H. (1984) "Reaction kinetics of the ferric chloride leaching of sphalerite-an experimental study," Metallurgical Transactions $B$, 10.1007/BF02661056.

Levenspiel, O. (1972) Chemical reaction engineering. 2nd ed. Published by John Wiley \& Sons Inc.

Liriden, J. (1999) "Overview of tantalum and niobium industries for 1998 and 1999," Tantalum-niobium International Study Centre Bulletin, 100, pp. 2-5.

Lv, Z., Wei, M., Wu, D., Liu, C., Zhao, D. and Feng, A. (2012) "A new technology for processing niobite ore found in Jiangxi province," International Journal of Mining Science and Technology, 22(4), pp. 579583. doi: 10.1016/j.jmst.2012.01.023.

Morrison, G. H. and Freiser, H. (1962) Solvent extraction in analytical chemistry. New York: John Wiley and Sons.

Nete, M., Purcell, W. and Nel, J. T. (2014) "Separation and isolation of tantalum and niobium from tantalite using solvent extraction and ion exchange," Hydrometallurgy, 149, pp. 31-40. doi: 10.1016/j.hydromet.2014.06.006.

Santos, F. M. F., Pina, P. S., Porcaro, R., Oliveira, V. A., Silva, C. A. and Leão, V. A. (2010) "The kinetics of zinc silicate leaching in sodium hydroxide," Hydrometallurgy, 102(1-4), pp. 43-49. doi: 10.1016/j.hydromet.2010.01.010

Szubert, A., Łupiński, M. and Sadowski, Z. (2006) "Application of shrinking core model to bioleaching of black shale particles," Physicochem. Probl. Miner. Process., 40(1), pp. 211-225. Available at: http://www.journalssystem.com/ppmp/Ap plication-of-shrinking-core-model-tobioleaching-of-black-shaleparticles, 79364,0,2.html.

Zhou, H., Zheng, S. and Zhang, Y. (2005) "Leaching of a low-grade niobiumtantalum ore by highly concentrated caustic potash solution," Hydrometallurgy, 80(1-2), pp. 83-89. doi: 10.1016/j.hydromet.2005.07.006. 
